Khrystyna Sobol, Zinoviy Blikharskyy, Nadiya Petrovska and Volodymyr Terlyha

\title{
AN ALYSIS OF STRUCTURE FORMATION PECULIARITIES DURING HYDRATION OF OIL-WELL CEMENT WITH ZEOLITIC TUFF AND METAKAOLIN ADDITIVES
}

\author{
Lviv Polytechnic National University \\ 12, S. Bandery str.,79013 Lviv, Ukraine; vterlyha@gmail.com
}

Received: January 14, 2014 / Revised: February 24, 2014 / Accepted: July 23, 2014

(c) Sobol Kh., Blikharskyy Z., Petrovska N., Terlyha V., 2014

\begin{abstract}
Investigations concerning the processes of plugging stone structure formation, using X-ray diffraction, electronic microscopy and differential thermal analyses, were implemented. Influence of active mineral additives of metakaolin and zeolite on the properties of plugging mortar and their interaction with Portland cement minerals with the aid of the model systems were established.
\end{abstract}

Keywords: oil-well cement, model systems, zeolite, metakaolin, physical and chemical analysis.

\section{Introduction}

Specific mining and geological conditions during the gas and oil deposits exploration and putting into operation require the use of plugging materials with programmed properties. As for example, for cementation of the boreholes with abnormally low stratum pressure, it is necessary to use the light-weight oil-well mixtures produced on the base of oil-well Portland cements with the light-weight mineral additives. In this case, the high value of water-cement ratio is used to provide the necessary (depending on the conditions) density of the cement mix (not more than $1.65 \mathrm{~g} / \mathrm{cm}^{3}$ ) holding the required spreading value, but high water content leads to bad sedimentation steadiness, increasing dehydration and filtration and decreasing the strength [1].

The mineral additives of both natural (bentonitic and palygorskitic clays, silica clay, zeolite) and anthropogenic (blastfurnace granulated slag, fly-ash) origin are used as light-weight additives to oil-well cements. Being commonly characterized by large specific surface and low fill dam, they differ by chemical and mineralogical content, particle form and size distribution, water absorption and water retention, as well as by their activity concerning their interaction with Portland cement hydration products [2]. It is obvious that the presence of light-weight additives in oil-well cements decreases the clinker content in the system and results in deceleration of the hydration and hardening processes, and strength reduction. So, when matching light-weight additives, fitting criterion should be based not only on abovementioned properties but on their capability to participate in the processes of oil-well cement structure formation.

\section{Experimental}

The possibility and expediency of combined introduction of zeolite and metakaolin as light-weight additives were proposed by us for the first time and they demanded urgently the studying of their behavior in the processes of hydration and hardening of oil-well cements [3]. The light-weight oil-well cements were produced on the basis of Portland cement PC I-500-H. Zeolitic tuff of A type from Sokirnycki deposit of Zakarpatsky region was used as zeolite-content formation (the content of zeolite is up to $90 \%$ ). The objective of this work was to understand the interaction of mineral additives that have binding properties, with calcium hydroxide, that is released at Portland cement hydration.

Zeolitic tuff is an effusive-sedimentary rock formation which is formed in the result of digenesis of igneous rocks and metasomatic exchange of alumosilicate glass by zeolite in them. Zeolite is a big similar by its composition and properties group of hydroalumosilicates of frame structure with a regular system of micro vesicles and channels where the exchangeable cations of alkaline, alkaline-earth metals and water molecules are located $[4,5]$. It is stated that the main zeolitic mineral in the investigated zeolitic tuffs is sodium clinoptilolit $\mathrm{Na}_{6}\left[\left(\mathrm{Al}_{2}\right)_{6} \cdot\left(\mathrm{Si}_{2}\right)_{30}\right] \cdot 24 \mathrm{H}_{2} \mathrm{O}$ and, as admixtures, quarts, feldspar, montmorillonite and calcite are presented (Fig. 1). 


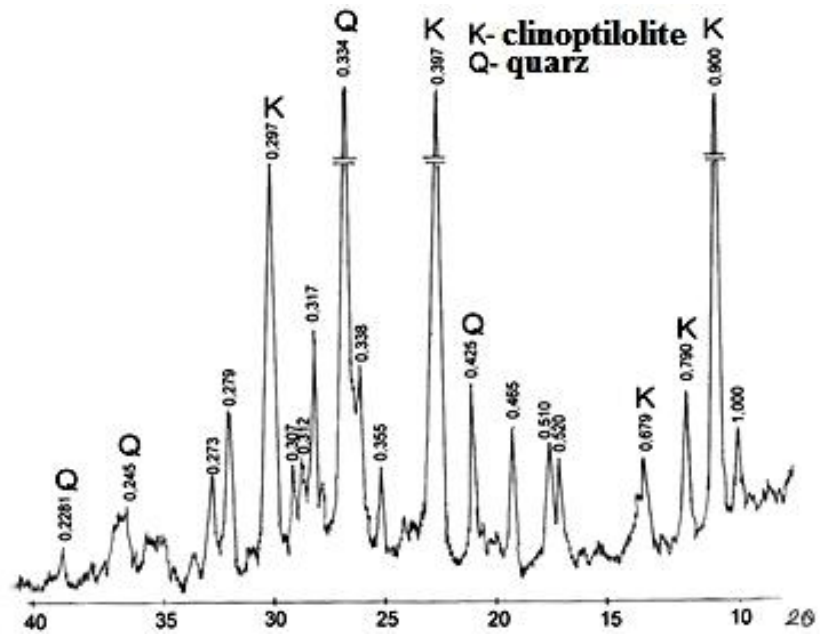

Fig. 1. X-ray diffraction pattern of natural zeolite from Sockirnycky deposit

According to X-ray diffraction data, on the first stage of zeolitic tuff specimen thermolysis the mass loss occurred in the temperature range of $293-473 \mathrm{~K}$. It is related to the "free" physically absorbed water releasing (Fig. 2). The second stage of specimen thermolysis occurs in the temperature range of $473-713 \mathrm{~K}$. It is related to the "structured" water releasing, which is coordinately and chemically combined with crystalline grade of the mineral and creates the aqua-complexes with cationic metals which are a part of seen on DTA curve of the specimen which is related to the process of surface dehydroxylation due to OH-group removal. The tiny mass loss on TG curve corresponds to it (Fig. 2).

In the the zeolitic structure.In the temperature range of 713-853 K, not deep endoeffect could be high temperature area of $853-1273 \mathrm{~K}$ on DTA curve the endothermic effect is observed which could be explained by coincidence of several processes: the deeper surface dehydroxylation, destroying and amorphization of zeolite crystalline structure under the influence of high temperatures.

Metakaolin is produced industrially by burning kaolin clay at the temperatures of $873-1073 \mathrm{~K}$. In the result of $\mathrm{Al}_{4}(\mathrm{OH})_{8}\left[\mathrm{Si}_{4} \mathrm{O}_{10}\right]$ dehydroxylation amorphous $\mathrm{Al}_{2} \mathrm{O}_{3} \cdot 2 \mathrm{SiO}_{2}$ is created which is characterized by increasing reactivity. In this work kaolin from clays of Glukhovecki deposit was used. It contains, along with amorphous component, admixtures of quartz and nondecomposed kaolin.

\section{Results and Discussion}

In contrast to classic natural pozzolanic additives which activity is determined by amorphous quartz, the activity of zeolite and metakaolin which contain

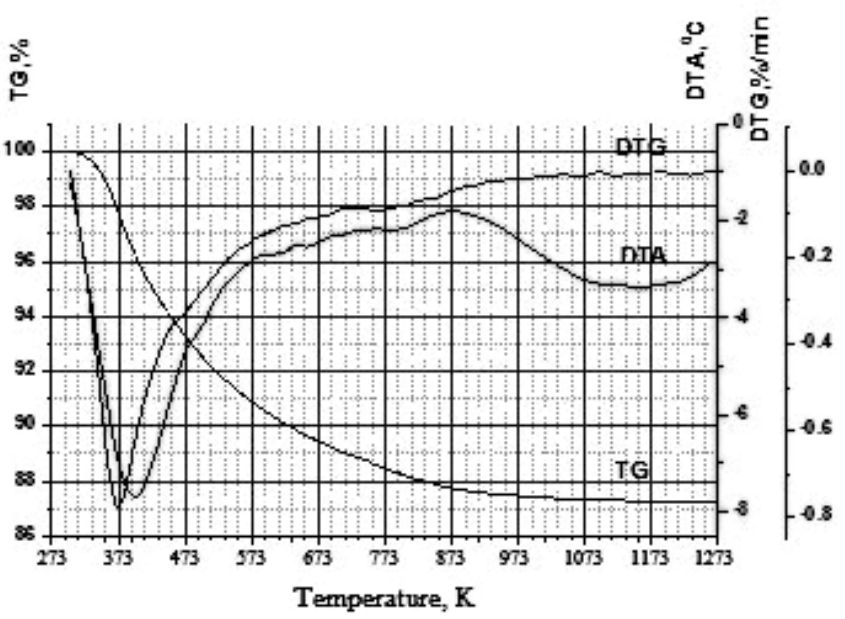

Fig. 2. DTA of natural zeolite from Sockirnycky deposit

chemically and thermodynamically non-stable phases is revealed by another mechanism. Study of their function in the processes of hydration and hardening of oil-well cement was beginning on the model systems which were investigated on the base of hydrated lime, zeolitic tuff (further "zeolite"), metakaolin and gypsum, which content corresponded to the relationship of the components in the cement (Table).

Activity of mineral components was determined by strength results when hardening at $348 \mathrm{~K}$ that correlates with conditions in geothermal boreholes with medium temperatures. It is stated that every component of the binding system facilitates better activity of other components. As for example, when introducing zeolite and metakaolin separately, the system strength is not high and makes 3.8-4.4 MPa. Their simultaneous use facilitates increasing of the system strength up to $8.7 \mathrm{MPa}$. The highest strength value was shown by the model system where zeolite and metakaolin were combined with gypsum. In this case the strength makes 11.5 and 12.2 $\mathrm{MPa}$ on the second and twenty eighth days of hardening, correspondingly, that from two to three times larger than for the systems where the additives were used separately. These results can be explained by existed mutual influence between the components of the model system. Simultaneous introduction of these components results in changing the mechanism of the binder system hydration so that received activity of the mixture increases and does not comply with the additivity law.

Analysis of X-ray diffraction patterns evidences that when introducing only one mineral component into the model system, the interaction rate in the system first of all depends on its nature and activity (Fig. 3). In the system $\mathrm{CaO}$-metakaolin on the second day of hardening along with the lines of $\mathrm{Ca}(\mathrm{OH})_{2}(d / n=0.262 ; 0.90 \mathrm{~nm})$ 
and metakaolin $(d / n=0.99 ; 0.71 ; 0.357 \mathrm{~nm})$, the lines of calcium hydrocarboaluminate $(d / n=0.76 \mathrm{~nm})$ and faint lines of hydrohelenite $\mathrm{C}_{2} \mathrm{ASH}_{8}(d / n=0.285 ; 0.279 ; 0.361$ $\mathrm{nm})$ are observed. In the system $\mathrm{CaO}-$ zeolite besides the lines of $\mathrm{Ca}(\mathrm{OH})_{2}$ and clinoptilolite $(d / n=0.90 ; 0.79 \mathrm{~nm})$, among the hydration products the lines of hydrohelenite $\mathrm{C}_{2} \mathrm{ASH}_{8}$ and sodium hydroalumosilicate $\mathrm{Na}_{2} \mathrm{O} \cdot \mathrm{Al}_{2} \mathrm{O}_{3} \cdot 4 \mathrm{SiO}_{2} \cdot 2 \mathrm{H}_{2} \mathrm{O}(d / n=0.228 ; 0.248 ; 0.273 \mathrm{~nm})$ could be observed. When two mineral additives - zeolite and metakaolin are introduced simultaneously, the line intensity of $\mathrm{Ca}(\mathrm{OH})_{2}$ decreases that evidences the more intensive interaction between the system components. The very intensive lines of such hydration products as calcium hydrocarbonate $(d / n=0.76 \mathrm{~nm})$, hydrogranate plazolite $\mathrm{C}_{3} \mathrm{ASH}_{4} \quad(d / n=0.505 ; 0.436 ; 0.260 \mathrm{~nm})$ and $\mathrm{Na}_{2} \mathrm{O} \cdot \mathrm{Al}_{2} \mathrm{O}_{3} \cdot 4 \mathrm{SiO}_{2} \cdot 2 \mathrm{H}_{2} \mathrm{O}(d / n=0.228 ; 0.248 ; 0.273 \mathrm{~nm})$ should be mentioned. Introduction of gypsum into the investigated multicomponent system results in appreciable changes in the processes of phase formation.

Distinctive characteristic of such hydroaluminate mineral additives as zeolite and especially metakaolin is their capability to react not only with $\mathrm{Ca}(\mathrm{OH})_{2}$, but also with gypsum creating additional quantity of calcium hydrosulphoaluminate. As it is evident from X-ray diffraction investigations, under normal hardening conditions the main hydrosulphoaluminate phase exists as ettringit $3 \mathrm{CaO} \cdot \mathrm{Al}_{2} \mathrm{O}_{3} \cdot 3 \mathrm{CaSO}_{4} \cdot 31 \mathrm{H}_{2} \mathrm{O}$.

Monohydrosulphoaluminate

$3 \mathrm{CaO} \cdot \mathrm{Al}_{2} \mathrm{O}_{3} \cdot \mathrm{CaSO}_{4} \cdot 12 \mathrm{H}_{2} \mathrm{O}$ is formed in small quantity (Fig. 4). When increasing the hardening temperature up to $323 \mathrm{~K}$, intensity of MGSAC lines $(d / n=0.892 ; 0.446 \mathrm{~nm})$ increases too but intensity of ettringit lines $(d / n=0.970$; $0.560 \mathrm{~nm}$ ) decreases. Increasing the temperature up to $348 \mathrm{~K}$ leads to further decreasing of ettringit lines intensity; MGSAC, which belongs to AFm-phases, becomes the basic hydrosulphoaluminate phase. These results are well correlated with the data obtained from electronic- microscopic investigations.

On the microphotographs of the investigated specimens the pile of hexagonal plates is observed which according to X-ray spectrum data could be attributed to monohydrosulphoaluminate (Fig. 5).

\section{Strength of model binding systems}

\begin{tabular}{|c|c|c|c|c|c|c|}
\hline \multicolumn{4}{|c|}{ Composition of binding system, mass parts } & \multirow{2}{*}{ W/S } & \multicolumn{2}{c|}{ Compression strength, MPa, in days } \\
\cline { 1 - 2 } \cline { 6 - 6 } $\mathrm{Ca}(\mathrm{OH})_{2}$ & Zeolite & Metakaolin & Gypsum & & 2 & 28 \\
\hline 1.0 & - & 0.5 & - & 0.65 & 3.8 & 4.3 \\
\hline 1.0 & 1.0 & - & - & 0.64 & 4.4 & 5.1 \\
\hline 1.0 & 1.0 & 0.5 & - & 0.69 & 8.7 & 9.5 \\
\hline 1.0 & 1.0 & 0.5 & 0.25 & 0.64 & 11.5 & 12.2 \\
\hline
\end{tabular}
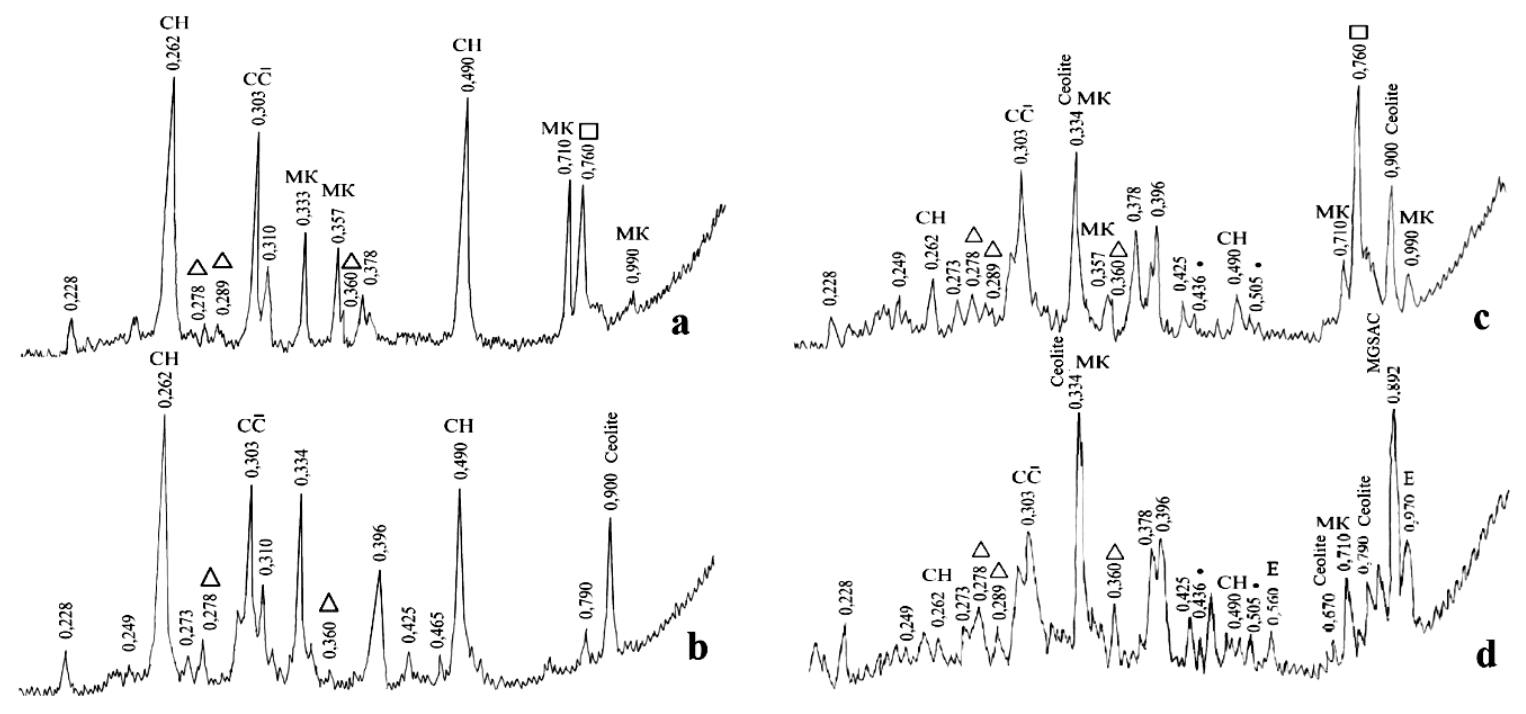

$\triangle-2 \mathrm{CaO} \cdot \mathrm{Al}_{2} \mathrm{O}_{3} \cdot \mathrm{SiO}_{2} \cdot 8 \mathrm{H}_{2} \mathrm{O} \bullet-3 \mathrm{CaO} \cdot \mathrm{Al}_{2} \mathrm{O}_{3} \cdot \mathrm{SiO}_{2} 4 \mathrm{H}_{2} \mathrm{O} \square-3 \mathrm{CaO}_{2} \cdot \mathrm{Al}_{2} \mathrm{O}_{3} \cdot \mathrm{CaCO}_{3} \cdot 12 \mathrm{H}_{2} \mathrm{O}$

Fig. 3. X-ray diffraction pattern of model systems hardened for two days at $348 \mathrm{~K}$ : calcium hydroxide-metakaolin (a); calcium hydroxide-zeolite (b); calcium hydroxide-metakaolin-zeolite (c) and calcium hydroxide-metakaolin-zeolite-gypsum (d) 


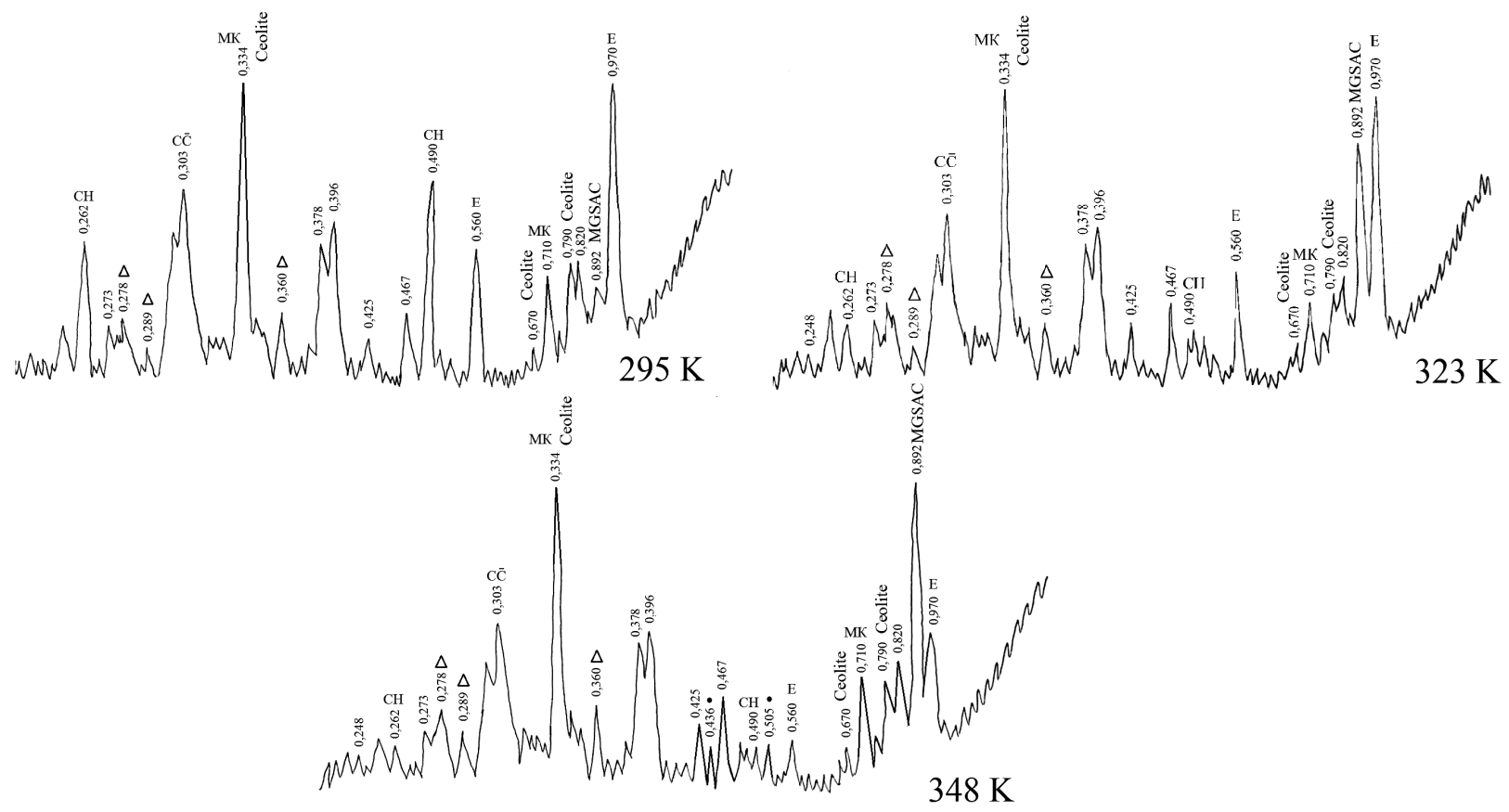

Fig. 4. X-ray diffraction pattern of model system "calcium hydroxide-metakaolin-zeolite-gypsum" at different hardening temperatures
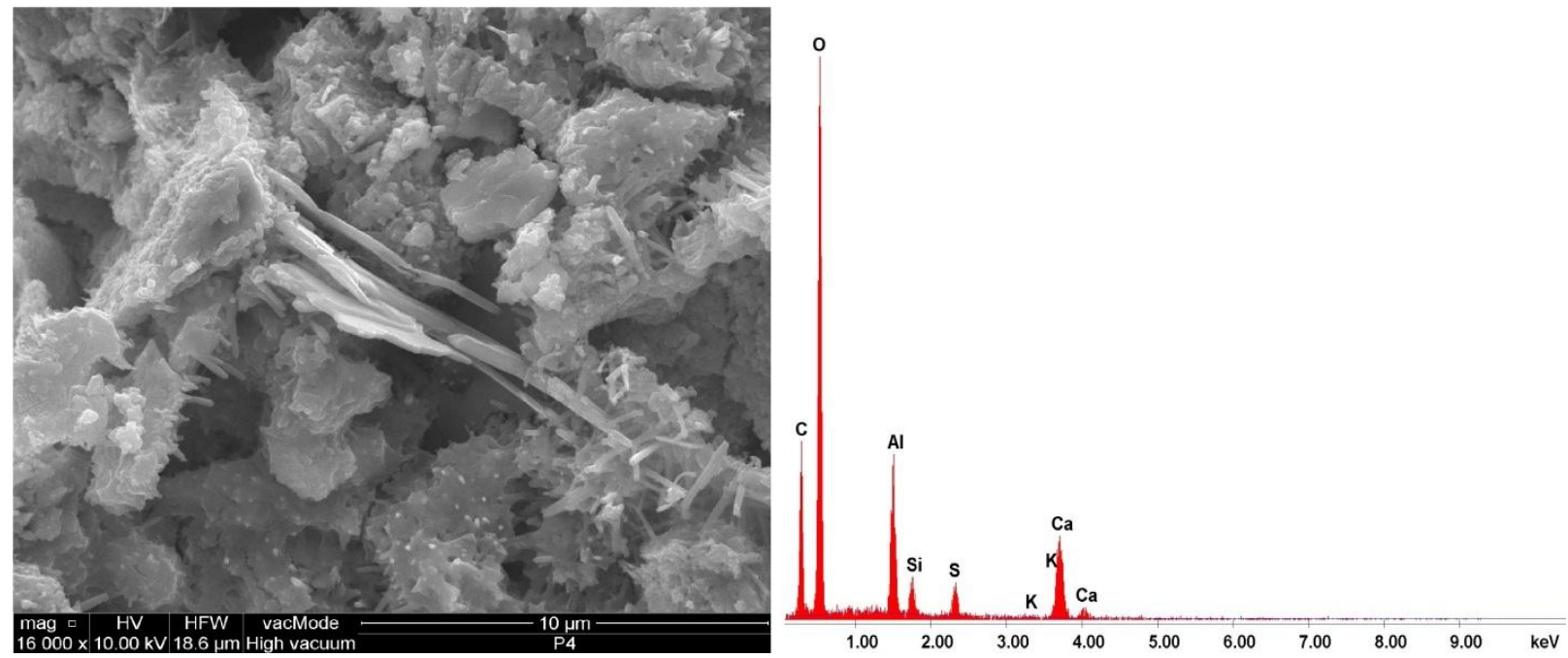

Fig. 5. Microstructure of oil-well cement stone

In many researchers opinion, MGSAC is a metastable phase and exists in the form of solid solution with hexagonal calcium hydroaluminate $\mathrm{C}_{4} \mathrm{AH}_{13}$ in which almost half of $\mathrm{OH}$-ions are exchanged by $\mathrm{SO}_{4}{ }^{2+}$ ions.

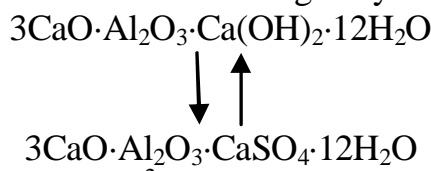

Presence of $\mathrm{SO}_{4}{ }^{2+}$ ions in the structure of formed hexagonal AFm-phases provides their stability, preventing their conversion into the cubic form that is especially important at increased temperatures of oil-well cement hardening.

So, in the process of hydration of model system "lime-zeolite-metakaolin-gypsum", calcium monohydrosulphoaluminate $3 \mathrm{CaO} \cdot \mathrm{Al}_{2} \mathrm{O}_{3} \cdot \mathrm{CaSO}_{4} \cdot 12 \mathrm{H}_{2} \mathrm{O}$ becomes one of the basic sulphoaluminate phases which stably exists at $348 \mathrm{~K}$ and provides the hardening system with stable properties without recrystallization and strength decrease. Moreover, among the hydration products of the investigated system hardened at $348 \mathrm{~K}$, the formation of one more AFm-phase-hydrohelenite 
$2 \mathrm{CaO} \cdot \mathrm{Al}_{2} \mathrm{O}_{3} \cdot \mathrm{SiO}_{2} \cdot 8 \mathrm{H}_{2} \mathrm{O}$ as well as hydrogranate plazoplite $3 \mathrm{CaO} \cdot \mathrm{Al}_{2} \mathrm{O}_{3} \cdot \mathrm{SiO}_{2} \cdot 4 \mathrm{H}_{2} \mathrm{O}$ is observed. This evidences that in the processes of containing zeolite and metakaolin oil-well cement hardening in geotermal environment, the phases typical for hydrothermal hydration conditions could be formed.

\section{Conclusions}

Considering the obtained results, it could be stated that the resulting activity of the component mix of the model system "lime-zeolite-metakaolin-gypsum" does not submit to the additivity law but shows the synergic character of interaction. Active structure formative role of zeolite and metakaolin in the hardening system consists in formation of additional quantity of AFm-phases, in particular stable towards conversion hexagonal hydrosulphoaluminate solid solution $3 \mathrm{CaO} \cdot \mathrm{Al}_{2} \mathrm{O}_{3} \cdot \mathrm{Ca}\left[(\mathrm{OH})_{2}\left(\mathrm{SO}_{4}\right)\right] \cdot 12 \mathrm{H}_{2} \mathrm{O}$, as well as hydrogranate-plazolite.

\section{Acknowledments}

This publication has been produced with the assistance of the European Union within the framework of Cross-Border Programme Poland - Belarus - Ukraine $2007-2013$. The contents of this publication are the sole responsibility of Lviv Polytechnic National University and can in no way be taken to reflect the views of the European Union.

\section{References}

[1] Erik B. and Guillot D.: Well Cementing, $2^{\text {nd }}$ edn. Schlumberger Educational Services, 2006.

[2] Terlyha V., Sobol Kh. and Tershak B.: $18^{\mathrm{h}}$ Int. Conf. on Building Mat., Germany, Weimar 2012, 0811.

[3] Sobol Kh., Sanitskiy M., Petrovska N. and Terlyha V.: Pat. UA 2012 02823, Publ. Sept. 25, 2012.

[4] Franus W.: Zastosowanie Zeolitow Wytworzonych z Popiolow Lotnych do Usuwania Zanieczyszcen z Wody i Sciekow. Polska Akademia Nauk, Lublin 2012.

[5] Stevulova N. and Mezencevova A.: Szesyty Nauk. Politechn. Rzesowskiej, Budown. i Inz. Srodowiska, 2004, 37, 407.

\section{АНАЛІЗ ОСОБЛИВОСТЕЙ \\ СТРУКТУРОУТВОРЕННЯ ПРИ ГІДРАТАЦІЇ ТАМПОНАЖНОГО ЦЕМЕНТУ З ДОБАВКАМИ ЦЕОЛТТОВОГО ТУФУ I МЕТАКАОЛІНУ}

\footnotetext{
Анотація. Проведено дослідження процесів структуроутворення тампонажного каменю з використанням рентгенофазового, електронно-мікроскопічного та диференційнотермічного аналізів. 3 використанням модельних систем встановлено вплив активних мінеральних добавок метакаоліну та цеоліту на властивості тампонажного розчину та їх взаємодію з портландцементними мінералами.

Ключові слова: тампонажні матеріали, модельні системи, цеоліт, метакаолін, фізико-хімічний аналіз, гідратаиія.
} 
